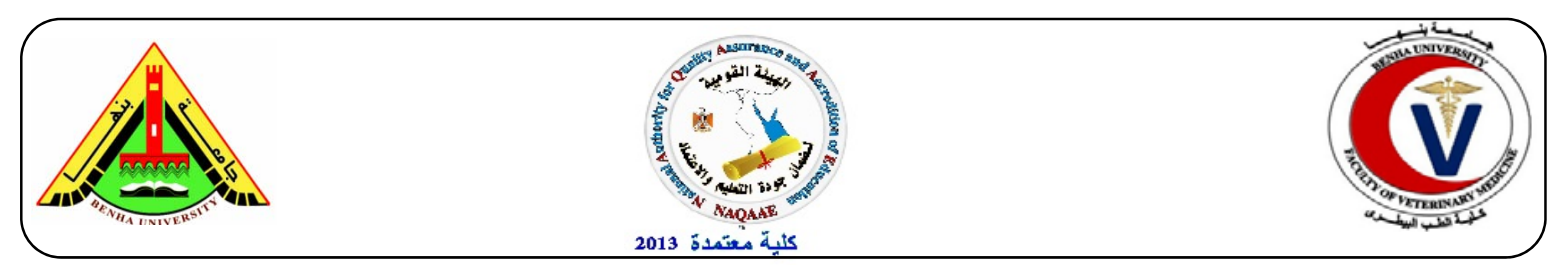

\title{
Some teratological effects of difloxacin in rats
}

\author{
Ashraf Elkomy, Mohamed Aboubakr, Nermin Medhat \\ Department of Pharmacology, Faculty of Veterinary Medicine, Benha University
}

\section{A B S T R A C T}

The aim of this experiment was to detect the teratogenic effects of difloxacin in Wister Albino rats. Thirty pregnant rats were divided into 3 groups; group (1) behaved as control and received normal saline. Group (2) was administered difloxacin at a dose of $20 \mathrm{mg} / \mathrm{kg} \mathrm{b}$. wt and group (3) was administered difloxacin at a dose of $40 \mathrm{mg} / \mathrm{kg} \mathrm{b}$. wt orally once daily from $6^{\text {th }}$ to $15^{\text {th }}$ day of pregnancy. The study revealed no teratogenic effect at a dose of $20 \mathrm{mg} / \mathrm{kg} \mathrm{b}$. wt, while at a dose of $40 \mathrm{mg} / \mathrm{kg} \mathrm{b}$.wt has significant teratogenic effect showed by decrease in size, weight, length, retarded growth in fetuses, fetal resorption of treated groups, the incidences of skeletal \& visceral abnormalities were increased in treated group ( $40 \mathrm{mg} / \mathrm{kg} \mathrm{b}$. wt). It could be concluded that. Administration of difloxacin during early stage of pregnancy and at high dose induce some fetal abnormalities.

Keywords: Difloxacin, Pregnancy, Visceral and Skeletal Abnormalities.

\section{INTRODUCTION}

$\mathrm{T}$ Teratology, the study of abnormal prenatal development and congenital malformations induced by exogenous chemical or physical agents, is a growing area of medical research in the quest for the eradication of preventable birth defects. Birth defects are known to occur in huge numbers roughly seven to ten percent of all children require extensive medical care to diagnose or treat a birth defect, this compromise the quality of life for millions of people worldwide. Almost all therapeutic agents cross placental barrier and enter fetal circulation. Every agent given during pregnancy therefore has a tendency to produce some sort of structural abnormality in the neonate at birth until proved otherwise (Schlegel et al., 1991). A birth defect or a congenital malformation is a structural abnormality of any type present at birth. It may be macroscopic or microscopic, on the surface or within the body (Moore, 1988). During the past few decades, it has become increasingly evident that human and animal embryos are subjected to the toxic effects of many drugs, such as the use of some antibiotics in the treatment serious diseases occurring during pregnancy. Fluoroquinolones are one of the main classes of antimicrobials used in the treatment of many infections. (Amwayi and Otiang, 1997). Fluoroquinolone antibiotics are commonly used to treat a variety of infections, including urinary tract, respiratory tract, gastrointestinal tract, skin, bone, and joint infections (Gurbay et al., 2002). The popularity of fluoroquinolone antibiotics has increased because of their broad antimicrobial spectrum, multiple approved indications, and favorable pharmacokinetics (Mehlhorn and Brown, 2007). Difloxacin is mainly used now for the treatment of urinary tract infections which have high incidence during pregnancy especially in the first trimester, and because difloxacin exert their effects via inhibition of nucleic acid synthesis, therefore this study was designed to evaluate the safety of difloxacin on embryonic development in rats. 


\section{MATERIAL AND METHODS}

\subsection{Animals}

Thirty female albino rats were aged 8-10 months, 200-250 gm b. wt., obtained from animal house colony of Faculty of Veterinary Medicine, Benha University. Rats were kept under hygienic conditions fed on standard balanced ration and water free from antimicrobials to withdraw any antibacterial residues. Female rats were examined periodically using vaginal smear technique to ensure that they were in regular estrous cycle. Two female in estrous phase was paired with a male of proven fertility in a separate cage. In the morning, vaginal smear was taken to verify day of pregnancy. Presence of spermatozoa in the obtained vaginal smear suspected pregnancy (Barcellona et al., 1977). Pregnancy was confirmed by persistence of diestrous state for 5 days. After mating, physiological bleeding disappears at $14^{\text {th }}$ day of gestation and palpable fetal masses in the abdomen at $15^{\text {th }}$ day after mating.

\subsection{Drug: Difloxacin (Diflobiotic $\left.{ }^{\circledR}\right)$}

Difloxacin is an active semi- synthetic fluoroquinolone. It is active against gram positive and gram negative germs, mycoplasma. It was manufactured by ATCO Pharmaceutical Industries, Egypt, under trade name (Diflobiotic ${ }^{\circledR}$ ). It is present in Plastic bottles contains $100 \mathrm{ml}$ solution. Each $1 \mathrm{ml}$ contains: difloxacin hydrochloride $109.13 \mathrm{mg}$ (eq. to $100 \mathrm{mg}$ difloxacin base).

\subsection{Experimental design}

Three groups contained ten pregnant female rats were used in this study as the following: Group (1): Ten pregnant rats were used as control group and received normal saline orally using stomach tube and sacrificed at $20^{\text {th }}$ day of pregnancy. Group (2): Ten pregnant rats were given therapeutic dose (20 mg/kg b.wt) of difloxacin orally using stomach tube from $6^{\text {th }}$ to $15^{\text {th }}$ day of pregnancy, rats were sacrificed at $20^{\text {th }}$ day of pregnancy to detect tetratogenic effects of difloxacin. Group (3): Ten pregnant rats were given high dose $(40 \mathrm{mg} / \mathrm{kg}$ b.wt) of difloxacin orally using stomach tube from $6^{\text {th }}$ to $15^{\text {th }}$ day of pregnancy, rats were sacrificed at $20^{\text {th }}$ day of pregnancy to detect tetratogenic effects of difloxacin.

\subsection{Teratological design}

Ten pregnant female rats of tested groups were sacrificed at the $20^{\text {th }}$ day of gestation and dissected to examine the effect of difloxacin on fetal development by morphological, visceral and skeletal examinations.

\subsection{Statistical analysis}

Analysis of variance (ANOVA) using Duncan's multiple range test for variables was computed for different parameters. Differences between group means were considered significant at $P<0.05$.

\section{RESULTS}

Oral administration of difloxacin at a dose $20 \mathrm{mg} / \mathrm{kg}$ b.wt to female pregnant rats from $6^{\text {th }}$ to $15^{\text {th }}$ of pregnancy produced no teratogenic effects, while oral administration of difloxacin at a dose 40 $\mathrm{mg} / \mathrm{kg} \mathrm{b}$.wt to female pregnant rats from $6^{\text {th }}$ to $15^{\text {th }}$ of pregnancy produced significant increase in number of resorbed fetuses per mother table (1). The obtained results indicated significant decrease in number of viable fetuses was recorded following administration of $40 \mathrm{mg} / \mathrm{kg}$ b.wt of difloxacin table (1). Statistical analysis of data revealed that difloxacin exerted significant decrease on fetal body weight and lengths were tabulated in table (2). Visceral examination of fetuses obtained from mother given a dose $(40 \mathrm{mg} / \mathrm{kg} \mathrm{b}$. wt) resulted in diverticulum dilation of the brain in $59.5 \%$, thymus hypoplasia in $43.4 \%$, pulmonary hypoplasia in $21.7 \%$ and cardiac enlargement in $26.1 \%$, hepatomegaly in $52.1 \%$, kidney hypotrophy in $60.8 \%$ and small size of suprarenal gland in $13.1 \%$ as shown in table (3). 
Skeletal examination of fetuses obtained from mothers given oral dose of difloxacin (40 $\mathrm{mg} / \mathrm{kg} \mathrm{b}$. wt) from $6^{\text {th }}$ to $15^{\text {th }}$ day of pregnancy showed impaired ossification of the skull in $68.42 \%$, Absence of digital bone of fore limb were recorded in $47.36 \%$, absence of sternbra in $47.36 \%$, absence of some metatarsal bone in $42.11 \%$ and some metacarbal bone in $36.84 \%$ of examined fetuses and absence of caudal vertebrae in $26.31 \%$ as shown in table (4).

Table (1) Effect of difloxacin on number of feti, viable, dead and resorbed feti per rat obtained from rats administered difloxacin at a dose of $20 \mathrm{mg} / \mathrm{kg} \mathrm{b}$. wt and $40 \mathrm{mg} / \mathrm{kg} \mathrm{b}$. wt orally once daily from $6^{\text {th }}$ to $15^{\text {th }}$ day of pregnancy.

\begin{tabular}{lccc}
\hline Parameter & Control & $\begin{array}{c}\text { Difloxacin } \\
(20 \mathrm{mg} / \mathrm{kg})\end{array}$ & $\begin{array}{c}\text { Difloxacin } \\
(40 \mathrm{mg} / \mathrm{kg})\end{array}$ \\
\hline No. of feti/rat & $8.60 \pm 0.31^{\mathrm{a}}$ & $8.30 \pm 0.21^{\mathrm{a}}$ & $5.59 \pm 0.34^{\mathrm{b}}$ \\
No. of viable feti/rat & $8.60 \pm 0.31^{\mathrm{a}}$ & $7.70 \pm 0.21^{\mathrm{b}}$ & $4.30 \pm 0.42^{\mathrm{c}}$ \\
No. of dead feti/rat & $0.0 \pm 0.0^{\mathrm{c}}$ & $0.0 \pm 0.0$ & $0.1 \pm 0.1$ \\
No. of resorbed feti/rat & $0.0 \pm 0.0^{\mathrm{c}}$ & $0.30 \pm 0.15^{\mathrm{b}}$ & $1.10 \pm 0.31^{\mathrm{a}}$ \\
\hline
\end{tabular}

$\overline{\mathrm{a}, \mathrm{b}, \mathrm{c}}$ Mean values having different letters in row differ significantly $(P<0.05)$.

Table (2) Morphological assessments of control and experimental delivered newborn feti obtained from rats administered difloxacin at a dose of $20 \mathrm{mg} / \mathrm{kg} \mathrm{b}$. wt and $40 \mathrm{mg} / \mathrm{kg} \mathrm{b}$. wt orally once daily from $6^{\text {th }}$ to $15^{\text {th }}$ day of pregnancy $(\mathrm{n}=10)$.

\begin{tabular}{lccc}
\hline Parameter & Control & $\begin{array}{l}\text { Difloxacin } \\
(20 \mathrm{mg} / \mathrm{kg})\end{array}$ & $\begin{array}{l}\text { Difloxacin } \\
(40 \mathrm{mg} / \mathrm{kg})\end{array}$ \\
\hline Fetal body length $(\mathrm{cm})$ & $4.04 \pm 0.03^{\mathrm{a}}$ & $3.95 \pm 0.05^{\mathrm{a}}$ & $2.98 \pm 0.06^{\mathrm{b}}$ \\
Fetal body weight $(\mathrm{g})$ & $3.95 \pm 0.07^{\mathrm{a}}$ & $3.82 \pm 0.06^{\mathrm{a}}$ & $2.91 \pm 0.07^{\mathrm{b}}$ \\
\hline
\end{tabular}

$\overline{\mathrm{a}, \mathrm{b}}$ Mean values having different letters in row differ significantly $(\mathrm{P}<0.05)$.

Table (3) Visceral abnormalities in the fetuses obtained from rats administered difloxacin at a dose of $20 \mathrm{mg} / \mathrm{kg} \mathrm{b}$. wt and $40 \mathrm{mg} / \mathrm{kg} \mathrm{b}$. wt orally once daily from $6^{\text {th }}$ to $15^{\text {th }}$ day of pregnancy $(\mathrm{n}=10)$.

\begin{tabular}{lcc}
\hline Abnormalities & Difloxacin $(20 \mathrm{mg} / \mathrm{kg})$ & Difloxacin $(40 \mathrm{mg} / \mathrm{kg})$ \\
\hline Brain & - & $59.5 \%$ \\
Thymus & - & $43.40 \%$ \\
Heart & - & $26.1 \%$ \\
Lungs & - & $21 \%$ \\
Liver & - & $52.1 \%$ \\
kidney & - & $60.8 \%$ \\
Suprarenal glands & - & $13.1 \%$ \\
\hline
\end{tabular}

Table (4) Skeletal abnormalities in the fetuses obtained from rats administered difloxacin at a dose of $20 \mathrm{mg} / \mathrm{kg} \mathrm{b}$. wt and $40 \mathrm{mg} / \mathrm{kg} \mathrm{b}$. wt orally once daily from $6^{\text {th }}$ to $15^{\text {th }}$ day of pregnancy $(\mathrm{n}=10)$.

\begin{tabular}{lcc}
\hline Abnormalities & Difloxacin $(20 \mathrm{mg} / \mathrm{kg})$ & Difloxacin $(40 \mathrm{mg} / \mathrm{kg})$ \\
\hline Skull & - & $68.42 \%$ \\
Sternebrae & - & $47.36 \%$ \\
Ribs & - & - \\
Metacarpal bone & - & $47.36 \%$ \\
Metatarsal bone & - & $42.11 \%$ \\
Digits bone & - & $36.84 \%$ \\
Coccygeal vertebrae & - & $26.31 \%$ \\
\hline
\end{tabular}




\section{DISCUSSION}

The current investigation aimed to study teratogenic effect of difloxacin in rat's fetuses. Oral administration of difloxacin at adose of $(20 \mathrm{mg} / \mathrm{kg}$ b.wt.) to pregnant rats didn't induce any teratogenic effects. Oral administration of difloxacin at adose of (40 $\mathrm{mg} / \mathrm{kg} \mathrm{b.wt}$.) to pregnant rats induced marked and significant decrease in the number of fetuses/ mother when compared with that recorded value of the control group without any fetal death. This result was consistent with the data reported by Eteng et al., 2008) following administration of perfloxacin in rats. Difloxacin at a dose of $(40 \mathrm{mg} / \mathrm{kg}$ b.wt.) resulted in marked decrease in number of viable fetus. This result was similar to those obtained by Tassinari et al. (1995) reported that, there was significant decrease in viable litter following administration of danofloxacin in pregnant rabbits. Difloxacin at a dose of (40 $\mathrm{mg} / \mathrm{kg} \mathrm{b}$.wt.) resulted in marked increase in the number of resorbed fetuses either early or late. This result was similar to that reported by Becker et al. (1987) following administration of enrofloxacin to pregnant rabbit; Kesseddjian et al. 1989a and Tassinari et al., (1995) following administration of danofloxacin in mice and rabbits respectively. Aboubakr et al., (2014) proved that, norfloxacin was significantly decreased the number of viable feti, increased the number of resorbed feti and induced retardation in growth of viable feti when given to pregnant rats. Administration of difloxacin at a dose of $(40 \mathrm{mg} / \mathrm{kg} \mathrm{b.wt}$.) to pregnant rats during the period of organogenesis produced significant decrease in both weight and length of fetuses. This result was consistent with several studies reported by Mobark (2010) and Siddiqui and Naqvi (2010).

Administration of difloxacin at dose of 40 $\mathrm{mg} / \mathrm{kg}$ b.wt to pregnant rats during the period of organogenesis induced many fetal visceral abnormalities as diverticulum dilatation in the brain of fetuses. This result was consistent with those reported by Minta et al. (2005) following administration of enrofloxacin and ciprofloxacin to albino Wister rat. Oral administration of difloxacin (40 mg/kg b.wt.) to pregnant rats resulted in hypoplasia of thymus gland. This result was similar to that reported by Hussy et al. (1986) following administration of ciprofloxacin and ofloxacin in which a dose of $100 \mathrm{mg} / \mathrm{ml}$ which inhibit cell growth but $1000 \mathrm{mg} / \mathrm{ml}$ led to cell death. Administration of difloxacin at a dose of (40 mg/kg b.wt.) to pregnant rats produced cardiac hyperplasia which is a dosedependent. This result was also agreed with Stahlmann (1990) following administration of ofloxacin and ciprofloxacin to immature animals. Administration of difloxacin at a dose of $(40 \mathrm{mg} / \mathrm{kg} \mathrm{b}$.wt.) to pregnant rats from $6^{\text {th }}$ to $15^{\text {th }}$ day of pregnancy induced pulmonary hypoplasia. Kim et al. (2000) reported that, after administration of DW116 to pregnant rats showed significant visceral abnormalities. Pulmonary hypopIasia might be attributed to extensive distribution into lung and achieved higher concentration (Gilfillan et al., 1984). Following administration of difloxacin to pregnant rats produced hepatomegaly and hypoplasia of one or both kidneys with unilateral or bilateral dilatation of renal pelvis. This result was similar to that reported by Schaefer et al. (1996) as there was about a $4.7 \%$ incidence of congenital malformation in live born children exposed to ciprofloxacin during the first trimester. Some fetal skeletal malformations were recorded such as impaired ossification of skull, absence of sternbrea, absence of digit's bone of fore and hind limb and absence of some metacarpal and metatarsal bone, reduction or absence of caudal vertebrae. This result agrees with that reported by many investigators as Kim et al (2000), kim et al (2005); Lemus et al., (2009); Mobark (2010) and Siddiqui and Naqvi (2010).

\section{CONCLUSIONS}


it could be concluded that administration of difloxacin during pregnancy especially in early stage \&at high doses could induce some fetal defects\& abnormalities, so it is advisable to avoid using of this drug during pregnancy.

\section{REFERENCES}

Aboubakr M, Elbadawy M, Soliman A,ElHewaity M. 2014. Embryotoxic and teratogenic effects of norfloxacin in pregnant female albino rats. Adv Pharmacol Sci. Doi: 10.1155/2014/924706.

Amwayi , P.J.A., Otiang'a-Owiti,G.E., 1997 "Useofbiometricembryonic growth parameters as indicator of exposure to a tera-togen,"East African Medical Journal,74,(1).6--11.

Barcellona, P., Fanelli,O. , Campana,A. 1977. "Teratological study of etoperidone in the rat and rabbit," Toxicology, 8(1).87--94.

Becker, H., Vogel, W.,Terrier, C.H.1987. Embryotoxicity (including teratogenicity) Study with BAY Vp 2674 in the Rabbit. Unpublished Report No. R4249 (Project No. 058555) from the Research Consulting Company AG, Itingen, Switzerland. Submitted to WHO by Bayer AG, Leverkusen, Germany (report No. 73705).

Eteng, M.U., Ukpanukpong, R.U., Abolaji, A.O., Eyong, E.U., Egbung, E. 2008. Biochemical and Histological Alteration and Effect of Perfloxacin on Wistar Rats Reproductive Function. Australian Journal of Basic and Applied Sciences. 2(3): 475-480.

Fernandes, P. B. 1988. "Mode of action, and in vitro and in vivo activ-ities of the fluoroquinolones," Journal of Clinical Pharmacology, 28, (2): 156--168,

Gilfillan, E.C., Pelak, B.A., Bland, J.A., Malatesta, P.F., Gadebusch, H.H. 1984. Pharmacokinetic Studies of Norfloxacin in Laboratory Animals Chemotherapy, 30: 288-296.
Gurbay, A.C, Garrel, M., Osman, M.-J., Richard, A., Favier, F.Hincal,2002. "Cytotoxicity in ciprofloxacin-treated human fibroblast cells and protection by vitamin E, "Human and Experimental Toxicology 21(12):635-641

Hussy, P., Mass, G., Tummler, B., Grosse, F., Schomburg, U. 1986. Effect of 4quinolones and novobiocin on calf thymus and polymerase $\alpha$ primase complex, topoisomerase I and II and growth of mammalian lymphoblasts. Antimicrob. Agents Chemother. 29 (6): 1073-1078.

Kesseddjian, M.J., Stadler, J., Paulus, G. 1989a. Danofloxacin Fetotoxicity study in mice by the oral route. Segment II. Unpublished studies No. 88115 and 88116 from Pfizer Central Research, Amboise Cedex, France. Submitted to WHO by Pfizer Inc., Groton, CT, USA.

Kim, J.C., Kim, S. H., Shin, D. H., Bae1, C.S., Oh1, K.S., Kim, J. H., Yun, H. I., Lim, J.H Chung, M.K.2005. Developmental toxicity assessment of the new fluoroquinolone antibacterial DW-116 in rabbits. Journal of Applied Toxicology 25(1): 52- 59.

Kim, J.C., Yun, H.I., Shin, H.C., Han, S.S., Chung, M.K.2000. Embryo lethality and teratogenicity of a new fluoroquinolone antibacterial DW116 in rats. ArchToxicol . 74(2): 1204.

Lemus, J.A.,Blanco, G.,Arroyo, B., Martínez, F. Grande J. 2009. Fatal embryo chondral damage associated with fluoroquinolones in eggs of threatened avian scavengers. Environ Pollut. ; 157(8-9): 2421-7.

Mehlhorn, A.J., Brown,D. A.,2007. "Safety concerns with fluoroquinolones "Annals of Pharmacotherapy 41(11):1859-1866 .

Minta, M. Wilk, I Zmudzki, J. 2005. Inhibition of cell proliferation by quinolones in micromass cultures of 
rat embryonic limb bud and midbrain cells. Toxicol in Vitro; 19: 915-919.

Mobarak, Y.M. 2010. Embryotoxicity and Teratogenicity of Enrofloxacin on Maternally Treated Chick. Asian Journal of Developmental Biology. 2: $1-15$

Moore, K. L., 1988. The Developing Human, WBSaunder, Philadel-phia, $\mathrm{Pa}$, USA, 4th edition.

Schaefer, C., Amuora, E.E., Vial, T., Orany, A., Garbis, H., Robert, E., Rodriguez, P.E., Pexieder, T., Prapas, N, Merlob, P., 1996. Quinolone exposure evaluation of a case registry of the European network of teratology information services. European journal of obstetrics and Gynecology and Reproductive Biology 69: 83-89.
Schlegel, P.N., Chang, T.S.K., Marshall,“F.F., 1991.Antibiotics:pote ntial hazards to male fertility, "Fertility and Sterility,.55(2): 235-242 ,

Siddiqui, M.A., Naqvi, S.H. 2010. Evaluation of the teratogenic potentials of ciprofloxacin in albino rat. J. Morphol. Sci. 27(1): 14-18

Stahlmann, R. 1990. Safety profile of the quinolones. J Antimicrob Chemother; 26(suppl D):31-44.

Tassinari, M.S., Laithwaite, H.T., Podurgiel, S.J., Gupta, U. 1995. Danofloxacin. Reproductive study III (teratology) in New Zealand white rabbits. Unpublished study No. 93607-34 from Pfizer Central Research, Groton, CT, USA. Submitted to WHO by Pfizer Inc., Groton, CT, USA. 